\title{
Birthweight in Congenital Virilizing Adrenal Hyperplasia
}

\author{
QUTUB H. QAZI and MARGARET W. THOMPSON \\ From Downstate Medical Center, Brooklyn, New York, U.S.A., and the Hospital for Sick Children, \\ Toronto, Ontario, Canada
}

\begin{abstract}
Qazi, Q. H., and Thompson, M. W. (1971). Archives of Disease in Childhood, 46, 350. Birthweight in congenital virilizing adrenal hyperplasia. Birthweights of 28 male and 38 female patients with congenital virilizing adrenal hyperplasia were compared with those of 27 male and 26 female unaffected sibs and newborns in Ontario. Only female patients were found to be significantly heavier than the female controls and female sibs. The mean birthweight of salt-losers was not significantly different from that of non-salt-losers. The female patients with more severe genital abnormalities did not have higher birthweight than those with less severe genital abnormalities.
\end{abstract}

The deficiency of C-21-hydroxylation in adrenocorticosteroid synthesis is the commonest cause of congenital virilizing adrenal hyperplasia (CVAH). Abnormal secretory activity in CVAH begins about the third month of gestation before the differentiation of external genitalia (Bierich, 1963). The masculinization of the female external genitalia noted at birth in almost all cases is thought to result from the androgenic action of excessive amounts of adrenal androgens produced by the fetal cortex. The rapid somatic growth and increased musculature in untreated patients are considered to be due to the protein anabolic effect of adrenal androgens which continue to be secreted postnatally in large amounts (Wilkins, 1965).

In the course of study of CVAH in Ontario, information regarding birthweight of patients with CVAH, their unaffected sibs, and newborn infants in the province of Ontario was obtained and the data were compared. This report summarizes our observations.

\section{Patients and Methods}

Seventy patients with C-21-hydroxylase deficiency were diagnosed at the Hospital for Sick Children, Toronto, in the period 1945-1967. In addition to characteristic clinical manifestations in the salt-losing and non-salt-losing patients, the diagnostic investigations included (1) estimation of urinary 17-ketosteroids and pregnanetriol before and after cortisone or dexa-

Received 8 December 1970. methasone administration; (2) $x$-rays for bone age; (3) intravenous pyelograms; and (4) sex chromatin study in female pseudohermaphrodites. In 3 cases the diagnosis was made at necropsy.

Most of the patients were referred to the hospital within a few weeks after birth. Information regarding birthweight and gestational age was obtained from the medical records, and was later verified in most instances by personal interviews with the parents. Data were available on 69 of 70 patients. Similar information was obtained about normal sibs of the patients, and about 3 affected sibs who had died earlier.

For birthweight analysis, only those children who were born after 37 weeks' gestation were used. The following 3 groups were compared: (1) affected children (28 male and 38 female); (2) normal sibs of the children in (1) above (27 male and 26 female); (3) children born in Ontario in 1960, used as population controls $(71,817$ male and 68,246 female).

The mean year of birth of patients in the present study was 1959, but since the 1959 Vital Statistics Report of Ontario did not include birthweight, 1960 was chosen as the nearest year.

\section{Results}

There were significantly more females with CVAH who had a birthweight of $3500 \mathrm{~g}$ or higher than expected (Table I). The mean birthweight of female patients was also significantly higher than that of their female sibs (Table II). Comparison of birthweight of male patients with male controls and their male sibs did not show similar differences. The mean birthweight of salt-losers was not 
significantly different from that of the non-saltlosers (Table III).

TABLE I

Observed versus Expected Frequencies of Birthweights in Male and Female Patients with CVAH

\begin{tabular}{|c|c|c|c|c|}
\hline \multirow{2}{*}{$\begin{array}{l}\text { Weight } \\
\text { Groups } \\
\text { (g) }\end{array}$} & \multicolumn{2}{|c|}{ Male Patients } & \multicolumn{2}{|c|}{ Female Patients } \\
\hline & $\begin{array}{l}\text { Observed } \\
\text { No. } \%\end{array}$ & $\begin{array}{l}\text { Expected } \\
\text { No. } \%\end{array}$ & $\begin{array}{l}\text { Observed } \\
\text { No. } \%\end{array}$ & $\begin{array}{l}\text { Expected } \\
\text { No. } \%\end{array}$ \\
\hline $\begin{array}{l}2000-3499 \\
3500-4999\end{array}$ & $\begin{array}{ll}11 & 39 \cdot 3 \\
17 & 50 \cdot 7\end{array}$ & $\begin{array}{ll}15 \cdot 1 & 53 \cdot 5 \\
12 \cdot 9 & 46 \cdot 0\end{array}$ & $\begin{array}{ll}15 & 42 \cdot 3 \\
23 & 60 \cdot 5\end{array}$ & $\begin{array}{ll}24 \cdot 8 & 65 \cdot 1 \\
13 \cdot 2 & 34 \cdot 4\end{array}$ \\
\hline
\end{tabular}

For males, $\chi_{2}=2 \cdot 416$, D.F., $1, P>0 \cdot 10$.

For females, $\chi_{2}=11 \cdot 149$, D.F., $1, P<0.005$.

TABLE II

Birthweights of Affected Children and their Normal Sibs

\begin{tabular}{lll|c|c|c|c}
\hline \multicolumn{1}{c|}{ Subjects } & & & No. & \multicolumn{2}{c|}{ Birthweight (g) } & P \\
\cline { 6 - 7 } & & & & Mean & S.D. & \\
\hline Male patients & $\ldots$ & $\ldots$ & 28 & 3,594 & 346 & $>0.20$ \\
Male sibs &. & $\ldots$ & 27 & 3,493 & 519 & \\
Female patients &. & $\ldots$ & 38 & 3,593 & 424 & $<0.001$ \\
Female sibs &. &. & 26 & 3,094 & 408 & \\
& & & & & & \\
\hline
\end{tabular}

TABLE III

Birthweights of Patients with Salt-losing and Nonsalt-losing Forms of CVAH

\begin{tabular}{ll|r|r|r|c}
\hline \multicolumn{1}{c|}{ Subiects } & & No. & \multicolumn{2}{|c|}{ Birthweight (g) } & \multirow{2}{*}{ P } \\
\cline { 5 - 6 } & & & Mean & S.D. & \\
\hline Salt-losing males & $\ldots$ & 20 & 3,651 & 350 & $>0.20$ \\
Non-salt-losing males & $\ldots$ & 8 & 3,452 & 309 & $>$ \\
Salt-losing females & $\ldots$ & 23 & 3,662 & 477 & $>0.20$ \\
Non-salt-losing females &.. & 15 & 3,488 & 314 & \\
& & & & & \\
\hline
\end{tabular}

The genital abnormalities of female patients were classified in 5 types according to Prader (1954). None of the patients had the rare type $\mathrm{V}$ abnormality. The mean birthweight of 28 patients with types III and IV (severe) abnormalities was not significantly different from that of 10 patients with types I and II (milder) abnormalities (Table IV).

\section{Discussion}

Clinically, 2 effects of androgenic steroids, the androgenic and anabolic, are well recognized. Since all available evidence suggests that there is an excessive production of androgenic steroids in
TABLE IV

Birthweights in Female Patients with Types I and II and Types III and IV Genital Abnormalities

\begin{tabular}{|c|c|c|c|c|c|c|c|}
\hline \multirow{2}{*}{\multicolumn{4}{|c|}{ Genital Types }} & \multirow{3}{*}{$\begin{array}{c}\text { No. } \\
10 \\
28\end{array}$} & \multicolumn{2}{|c|}{ Birthweight (g) } & \multirow{2}{*}{$\mathbf{P}$} \\
\hline & & & & & \multirow{2}{*}{$\begin{array}{l}\text { Mean } \\
3,542 \\
3,606\end{array}$} & \multirow{2}{*}{$\begin{array}{l}\text { S.D. } \\
274 \\
470\end{array}$} & \\
\hline $\begin{array}{l}I+I I \\
I I I+I V\end{array}$ & $\begin{array}{l}\cdots \\
\ldots\end{array}$ & $\begin{array}{l}\ldots \\
.\end{array}$ & . & & & & $>0.05$ \\
\hline
\end{tabular}

a fetus with CVAH, it would be expected that, by virtue of their anabolic action, these steroids would produce higher birthweight in affected infants.

Bergstrand (1966) compared the mean birthweight of 49 patients with CVAH (23 male and 26 female) with that of normal newborn Swedish infants. Though the mean birthweight of the patients was somewhat higher than that of the controls, the difference was not significant.

In the present study, only the female patients were found to be significantly heavier than their female sibs and the female controls. These observations raise the question as to why the male infants with CVAH did not have their weight significantly affected since they were exposed to androgens for the same period in utero as were the female infants.

Baldratti (1965) administered various androgenic steroids to adult male and female rats and observed that by every method of administration there was an increase of body weight of female rats over controls, whereas the anabolic action of these steroids on the weight of male rats was neither consistent nor unequivocal.

Though it is difficult to compare the effects of androgens in the adult rat and the human fetus, Baldratti's findings seem to have a parallel to the observations made during the present study. It is known that male fetuses are normally exposed to androgenic substances produced by their testes. It may be that the differences in weight gain between male and female fetuses with CVAH are due to greater end organ responsiveness of the female tissues to the anabolic effects of androgens. It is also possible that in the male fetus there is already maximal androgenic stimulus to growth and the presence of more androgen does not produce greater growth.

Because of a more severe disturbance of corticosteroid synthesis, greatly increased production of androgens would be expected to occur in salt losers during fetal life. However, the mean birthweight of salt losers was not significantly higher than that of non-salt-losers. Similarly, an attempt 
to correlate birthweight to the severity of genital defects in female patients did not show the mean birthweight of patients with the more severe genital abnormalities to be higher than that of patients with the milder abnormalities. The absence of significant correlation between the birthweight and severity of genital abnormalities may be due to a rather low ratio of anabolic to androgenic effects of the androgens produced by the fetal adrenal cortex (Suchowsky and Junkman, 1965).

Correspondence to Dr. Q. H. Qazi, Downstate Medical Center, 450 Clarkson Avenue, Brooklyn, New York 11203, U.S.A.

\section{REFERENCES}

Baldratti, G. (1965). The biological evaluation of the anabolic activity. In Hormonal Steroids: Biochemistry, Pharmacology and Therapeutics: Proceedings of the First International Congress on Hormonal Steroids, vol. II, p. 173. Ed. by L. Martini and A. Pecile. Academic Press, New York.

Bergstrand, C. G. (1966). Growth in congenital adrenal hyperplasia. Acta Paediatrica, 55, 463.

Bierich, J. R. (1963). The adrenogenital syndrome. In Intersexuality, p. 345. Ed. by C. Overzier. Academic Press, London and New York

Prader, A. (1954). Der Genitalbefund beim Pseudohermaphroditismus feminis des kongenitalen adrenogenitalen Syndroms. Helvetica Paediatrica Acta, 9, 231.

Suchowsky, G. K., and Junkman, K. (1965). Recent findings in anabolic steroids. In Hormonal Steroids; Biochemistry, Pharmacology and Therapeutics: Proceedings of the First International Congress on Hormonal Steroids. vol. II, p. 115. Ed. by L. Martini and A. Pecile. Academic Press, New York.

Wilkins, L. (1965). The Diagnosis and Treatment of Endocrine Disorders in Childhood and Adolescence, 3rd ed., p. 401. Thomas, Springfield, Illinois. 